日本大腸肛門病会誌 $61 ： 527-533,2008$

症例報告 I

長期経過中の内視鏡検査で発見されたクローン病関連大腸癌の 1 例

\author{
中村 光一 ${ }^{1)}$ 中村 利夫 $^{11}$ 倉地 清隆 ${ }^{11}$ 林 忠毅1) 中島 昭人 ${ }^{1}$ \\ 深沢 貴子 ${ }^{1)}$ 鈴木 昌八 ${ }^{1)}$ 今野 弘之 ${ }^{1)}$ 馬場 聡 ${ }^{2}$ \\ 浜松医科大学第 2 外科 ${ }^{12}$, 同 病理部 ${ }^{21}$
}

症例は 33 歳女性. 18 歳より潰瘍性大腸炎として, 年 1 回の大腸内視鏡検查を施行されていた. 平成 18 年の大腸内視鏡検査にて, 横行結腸の生検部位から高中分化腺癌を認め, 当科紹介となった. 大腸内視鏡 再検査にて横行結腸に強い炎症をともなう，不整顆粒状，結節状変化を認め，同部位の生検にて小型類上 皮肉芽腫を認めた，以上より，クローン病に合併した colitic cancer と診断し，腹腔鏡下結腸亜全摘，回腸 直腸吻合術を施行した，病変は IIc 様であり，病理所見にて， $35 \times 18 \mathrm{~mm}$ の粘液産生の著明な高分化腺癌 で, 病変部周囲に dysplasia を認め, 深達度は pSS, リンパ節転移は pN0 で, クローン病に合併した横行 結腸癌の診断となった。今回我々はクローン病病変部に横行結腸癌が合併し，周囲にdysplasia を認めた 症例を経験したので若干の文献的考察を加えて報告する.

索引用語 : クローン病, 大腸癌, Dysplasia

はじめに

クローン病に合併した大腸癌は欧米では多く報告 されているが，本邦ではまだ少ない。しかし，近年 本邦においても報告例が徐々に増加してきており, 今後クローン病患者やその長期経過例の増加にとも ない, 癌合併症例が増加することが予測される. 今 回我々は潰瘍性大腸炎として 10 年以上 follow され たクローン病病変部に横行結腸癌が合併した症例を 経験したので文献的考察を加えて報告する.

\section{症例}

患者 : 33 歳, 女性.

主訴：サーベイランス内視鏡後の精査, 加療目的.

家族歴：特記すべきことなし.

既往歴：肛門疾患による手術既往あり。

現病歴：1990 年 (17 歳) から下痢, 発熱, 腹痛が 半年以上持続. 近医受診し, 大腸内視鏡検査施行し, 潰瘍性大腸炎（全大腸炎型）の診断にて保存的治療 開始となった. 以後年 1 回のサーベイランス内視鏡 を施行していた. 2006 年 6 月, 大腸内視鏡検査にて, 横行結腸からの Biopsyにて高中分化腺癌と診断さ れ, 同年7月,精査・加療目的にて当科紹介受診した.
理学所見：身長 $156 \mathrm{~cm}$, 体重 $56 \mathrm{~kg}$, 脈拍 $65 /$ 分 整, 体温 $36.9^{\circ} \mathrm{C}$, 血圧 $108 / 60 \mathrm{mmHg}$. 腹部に自発痛, 圧痛認めず，腫瘤も触知しなかった，排便回数は 1 日 4〜5 回程度であり, 血便は認めなかった. IOIBD score は 0 点であった.

入院時検査成績 : 血液生化学所見では, 軽度の貧 血 $(\mathrm{Hb}: 10.3 \mathrm{~g} / \mathrm{d} l)$ と炎症所見 $(\mathrm{CRP}: 0.19 \mathrm{mg} / \mathrm{d} l)$ を 認めた. 腫瘍マーカー (CEA : 1.8ng/ml, CA19$9:<1 \mathrm{U} / \mathrm{ml})$ は正常範囲内であった.

大腸内視鏡検査：回腸末端に炎症をともなうポ リープ様隆起を認め（図 1a), Bauhin 弁は変形が強 く, 硬化, 開大を認めた (図 1b). 横行結腸肝彎曲寄 りに，領域性のある発赤をともなう不整形の浅い陥 凹を認めた(図 1c). 同部位の前医生検で高中分化腺 癌の診断であった。下行結腸から直腸にかけては著 明な炎症所見は認めなかった。

腹部単純 $\mathbf{X}$ 線検査 : 大腸内視鏡検査直後の腹部 単純 X 線検査にて横行結腸は正常な haustra がな く鉛管状変化を認め, 肝彎曲寄りに狭窄, 進展不良 をともなっていた（図 $2 \mathrm{a}$ ).

腹部 CT 検査 : 横行結腸近位部に壁肥厚を認め, 脾彎曲部や上行結腸にも軽度の壁肥厚が見られた。 明らかに腫大したリンパ節や肝内の結節性病変は認 


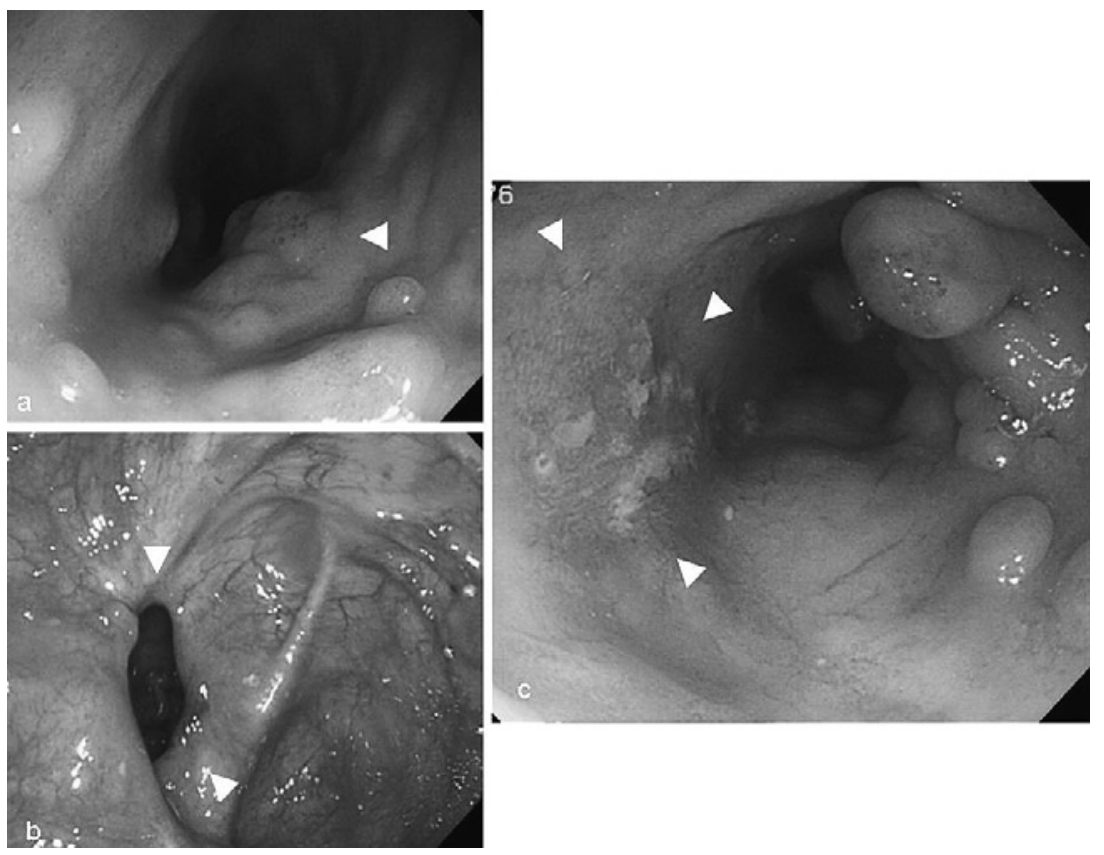

図 1 大腸内視鏡検査

a, b : 回腸末端炎症をともなうポリープ様隆起を認め, Bauhin 弁は変形が強く, 硬化, 開大を認めた。

$\mathrm{c}$ ：横行結腸肝彎曲寄りに, 領域性のある発赤をともなう不整形の浅い陥凹を認めた.

めなかった（図 $2 \mathrm{~b})$.

以上より，治療の結果による修飾が加わった可能 性もあるが, 内視鏡所見にて病変が肛門側から連続 していないこと，小腸にも炎症所見を認めること， 肛門疾患の既往を有することから背景疾患として潰 瘍性大腸炎よりはクローン病を疑い，クローン病に 合併した横行結腸癌の診断にて手術を施行した。

手術所見：横行結腸を中心に著明な壁肥厚を認め た. 小腸では, 回腸末端から口側 $10 \mathrm{~cm}$ にかけて著明 な壁の肥厚像と拡張像，さらに回腸末端から約 130 $\mathrm{cm}$ の部位に fat wrapping をともなう狭窄像を認 め, クローン病による変化と診断した．以上の所見 に対して腹腔鏡補助下結腸全摘, D2 郭清, 回腸部分 切除，回腸直腸側端吻合術を施行した。

切除標本肉眼所見：上行結腸に約 $26 \mathrm{~cm}$ にわたる 縦走潰瘍, 横行結腸では約 $17 \mathrm{~cm}$ にわたりびらんを ともなう polypoid lesion(図 3a)，また横行結腸肝彎 曲寄りに，領域性のある発赤をともなう不整形の浅 い陥凹を認めた（図 $3 \mathrm{~b}$ )。また，小腸の腸間膜側に縦 走潰瘍を認めたが，下行結腸から S 状結腸には散在 性に浅いびらんを認めるのみであった（図 3a）.

病理組織学的検査所見：病理組織検査では，背景
の炎症所見に関しては，粘膜下層を中心に巨細胞と 萎縮した類上皮細胞からなる孤立性の肉芽腫を認め (図 3c), さらに全層性の炎症細胞浸潤を認めたため クローン病による変化と診断した。腫瘍部分では, 筋層を超え, 漿膜下組織に浸潤した粘液産生が豊富 な腺癌を認め，粘液癌と診断した。浸潤部表層では 高分化腺癌が主体であった. SM 以深の浸潤癌部分 の周囲には本邦では粘膜内癌と診断されるような high grade dysplasia の拡がりを認めた（図 4).p53 免疫染色を施行したところ，浸潤部，表層部ともに p53 の過剩発現を認め, その周囲の dysplasia 部位で も過剩発現を認めた（図 5)。さらに浸潤癌部から離 れた部位では，HE 染色では再生異型と鑑別が困難 とも思われる軽度の異型を認めたが, p53 染色にて 陽性であり, low grade dysplasia と診断した(図 5)。 また，Ki-67 免疫染色を施行したところ high grade dysplasia では明らかに正常粘膜に比べ強陽性に染 まり, low grade dysplasia も正常部分と比較してや や染まりが強かった（図6）.

術後経過：術後特に合併症なく経過し退院した. 術後約 14 力月経過した現在，無再発生存中である. 


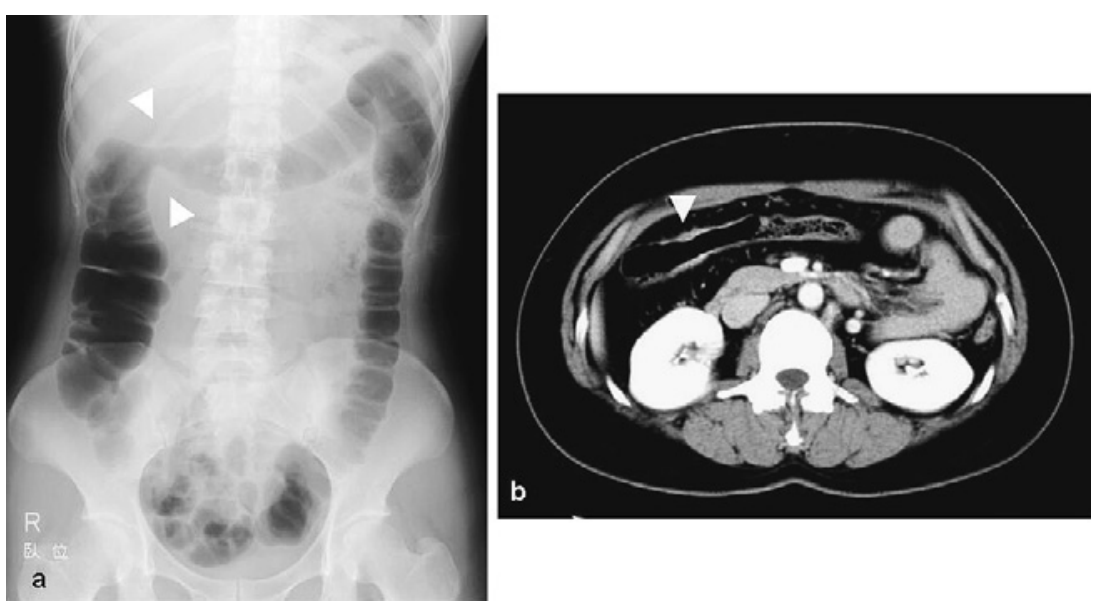

図 2 腹部単純 $\mathrm{X}$ 線検査, 腹部造影 $\mathrm{CT}$ 検査

$\mathrm{a}$ : 腹部単純 $X$ 線検査

横行結腸は鉛管状変化を認め, 肝彎曲寄りに狭窄, 伸展不良をともなっていた.

$\mathrm{b}$ : 腹部造影 $\mathrm{CT}$ 検査

横行結腸近位部に壁肥厚を認めた.

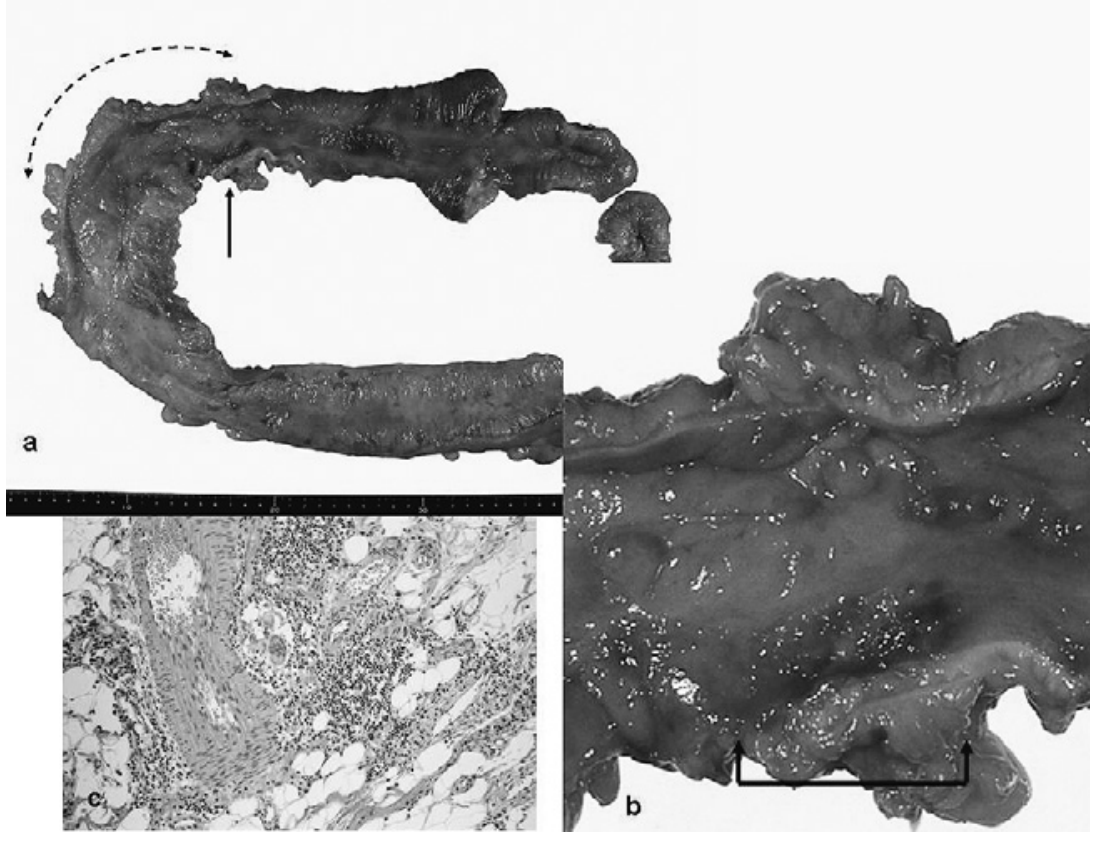

図 3 摘出標本

$\mathrm{a}$ ：上行結腸に約 $26 \mathrm{~cm}$ にわたる縦走潰瘍，横行結腸では約 $17 \mathrm{~cm}$ にわたりびらんをともな

う polypoid lesion（点線範囲）と発赤をともなう不整形の浅い陥凹性病変（矢印）を認 めた。

$\mathrm{b}$ ：陥凹性病変の拡大写真. (矢印：病変部)

$\mathrm{c}$ ：粘膜下層を中心に, 巨細胞と萎縮性類上皮細胞からなる孤立性の肉芽腫を認めた.

考察

潰瘍性大腸炎 (以下 UC) の長期経過例に大腸癌の
合併率が高いことはこれまで多く報告されてきた. 欧米においては, クローン病 (以下 CD) に合併した 大腸癌も多く報告されており，Canavan ら¹)による 


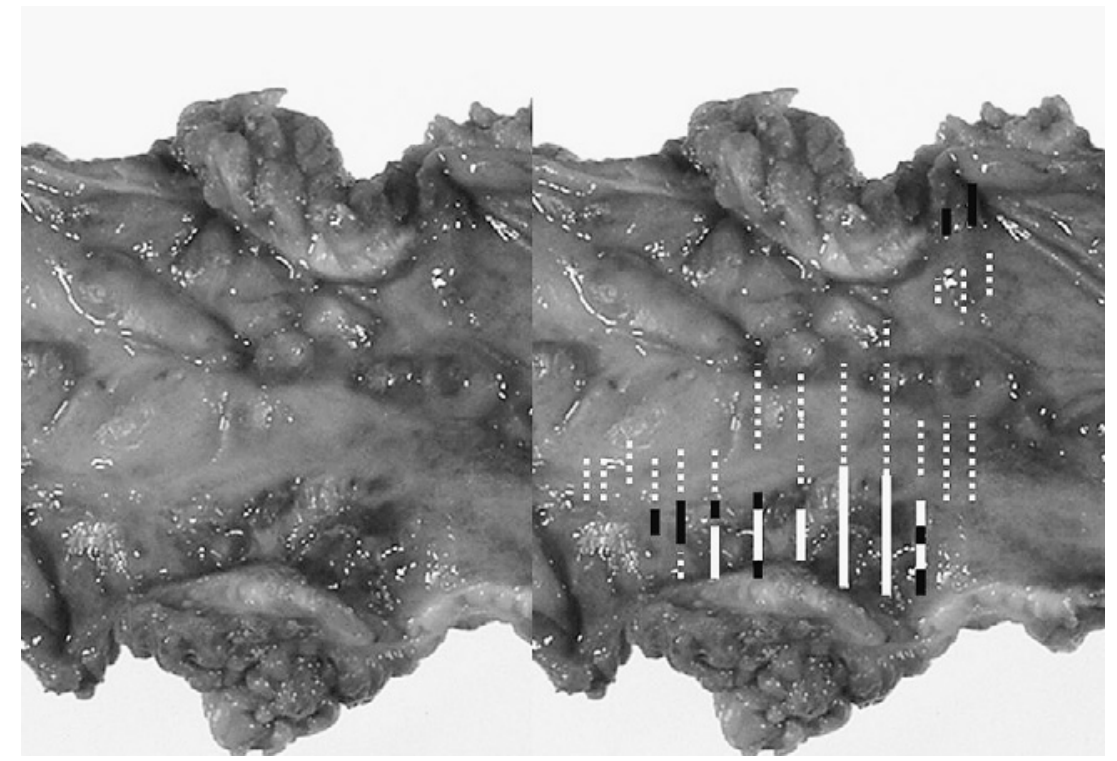

図 4 病変範囲

(白実線：MP 以深癌, 黒実線： $\mathrm{sm}$ 癌, 点線：粘膜内病変)

meta-analysis の結果では CD にともなう大腸癌の 罹患相対危険率は 2.5 であり，病型別にみると大腸 型 CD では 4.5, 小腸型では 1.1 と報告されている. また最近, Alexander ら ${ }^{2)}$ はCD 患者 60,122 例の meta-analysis を行い, 大腸癌の罹患相対危険率を 2.4 と報告している. 近年, 本邦においてもクローン 病患者やその長期経過例の増加にともない, 大腸癌 合併例の報告が増加してきている.

欧米では，一般の大腸癌に比べ癌の発生部位の近 傍にdysplasia が高頻度にみられるという報告があ る ${ }^{3,4}$ が, 本邦の報告では dysplasia がみられたという 報告は少ない ${ }^{5)}$. 本症例では SM 以深浸潤癌部に近接 して周囲にdysplasiaの拡がりを認めており, sporadic な大腸癌よりも, クローン病病変部に発生した colitic cancer と診断した。本症例では深達度 SS の 進行癌であったにもかかわらず，粘膜面の変化も弱 かったため, 腫瘍部での癌と dysplasia の組織学的 鑑別が可能であったと考えられる。

CD に合併した大腸癌と p53 遺伝子の過剩発現が 注目されており, 通常の大腸癌では p53の過剩発現 が 47\% にみられたが, CD に合併した癌においては $73 \%$ にみられたとの報告がある ${ }^{6)}$. 本症例において も，浸潤部において p53 免疫染色が強陽性を示して おり, HGD や LGD の部位でも正常部分と比較して 陽性細胞が多かった．また，Ki-67 に関しても正常部
分と比較して, 浸潤癌部, dysplasia 部において過剩 発現を認めた. UC の癌合併では, 腺管中層から深部 に増殖帯が存在し, 表層に向かって細胞分化を示す とされるが，本症例では増殖帯の部位に関しては表 層部と中層〜基底部の違いは明暸ではなかった.

$\mathrm{UC}$ に対しては, 長期経過例に対し, 癌の早期発見 を目的としたサーベイランスが勧められている一方 で，CD に対するサーベイランスの意義については いまだ統一した見解は得られていない.Friedman らは，CDにともなう colitic cancer の予防サーベイ ランスを内視鏡で行い，有効であったとしている77. またAlexnder $ら^{2)}$ は広範な大腸病変を有する患者 ではサーベイランス内視鏡が推奨されるとしてい る. 当科ではこれまでに 3 例のクローン病関連大腸 癌を経験しているが, いずれも有症状であり, リン パ節転移陽性の進行癌であった（表 1)。本症例も粘 膜面の変化に比べ深部浸潤をきたした癌であり, サーベイランス内視鏡を施行していなければ発見が 遅れた可能性があった。

しかし，潰瘍性大腸炎やクローン病に合併する大 腸癌の特徴は, 扁平, 平坦で, びまん浸潤性, 境界 不明瞭な肉眼型を呈し，筋層以深に浸潤しても表面 の凹凸変化が少ない病変もまれではないため，その 診断は必ずしも容易ではない.サーベイランス法に ついてはUCにおけるステップバイオプシーの有効 

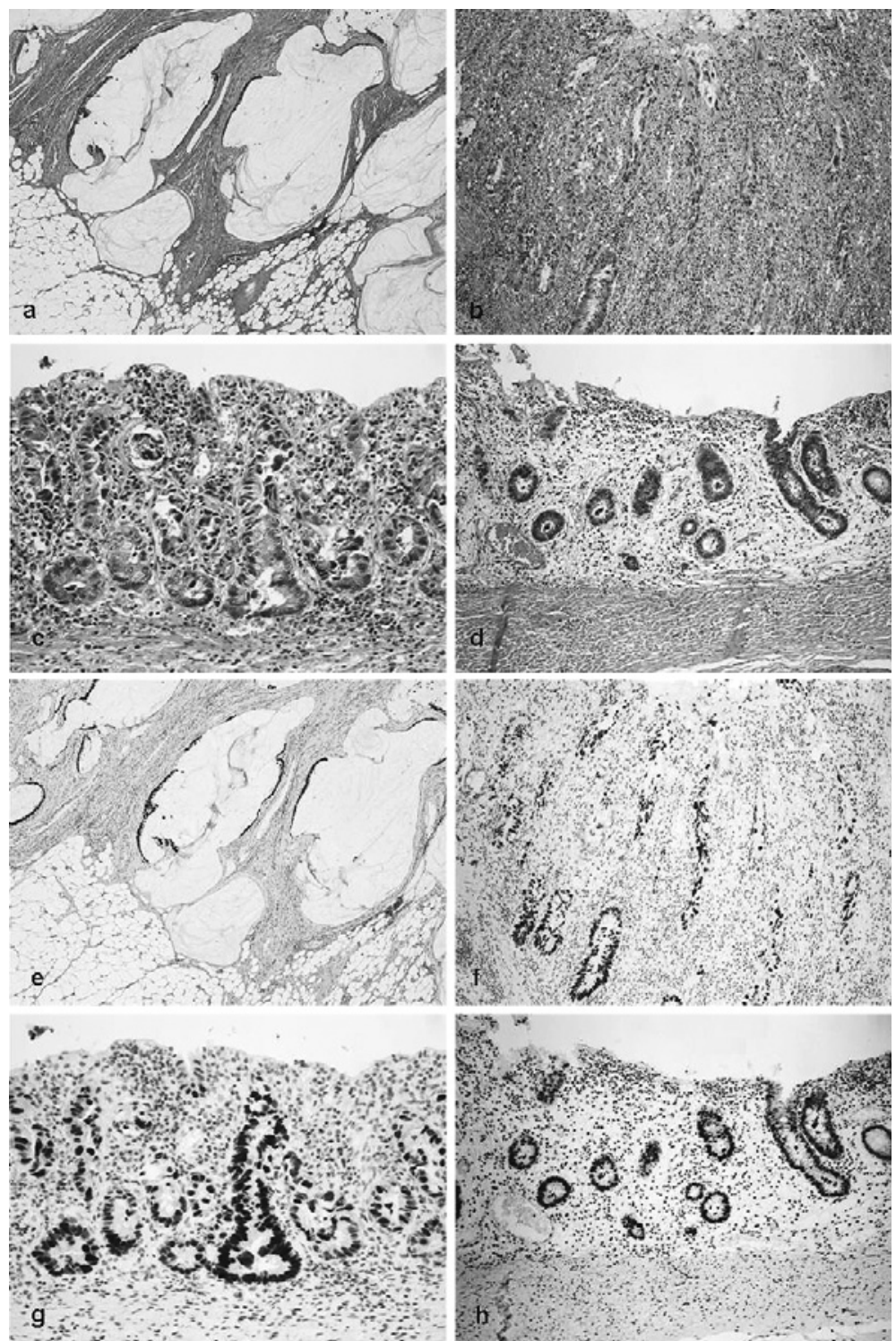

図 5 HE 染色像, p53 免疫染色像

$\mathrm{a}, \quad \mathrm{b}$ ：漿膜下組織に浸潤した粘液産生が豊富な腺癌を認めた。（a：浸潤部， b : 表 層部)

$\mathrm{c}, \mathrm{d}$ ：腺癌組織の周囲に dysplasia を認めた。（c：HGD, d ：LGD）

$\mathrm{e} \sim \mathrm{h}$ : 同部位の p53 免疫染色

性に関しては疑問視されており, CD においても生 検のターゲットとする所見に関しては検討が必要と 思われる. dysplasia の色調については, 切除標本の 検討から発赤として観察される可能性を示唆する報 告がある ${ }^{8)}$. 本症例では, dysplasia 部分だけを見る と, 術前の通常観察のみでは周囲の緩解粘膜との違 いとして捉えることはできなかった. したがって， 色素散布や拡大内視鏡などの使用は必要であろうと 考える. また, 以前より CD 合併大腸癌は狭窄部に発
症しやすいとされており, 本症例も狭窄部に発生し た癌であった。したがって, 粘膜面に癌を疑う明ら かな変化がなくても狭窄部周囲は生検の夕ーゲット とすべき所見のひとつと考える.

\section{まとめ}

クローン病に合併した横行結腸癌の 1 例を経験し たので報告した，本邦においても，クローン病患者 やその長期経過例の増加にともない, 今後のサーベ 
表 1 当院のクローン病合併大腸癌症例

\begin{tabular}{|c|c|c|c|c|c|c|c|}
\hline 性別 & $\begin{array}{c}\text { 実年齢 } \\
\text { (発症年齢) }\end{array}$ & $\begin{array}{c}\text { クローン病 } \\
\text { 罹病期間 } \\
\text { (年) }\end{array}$ & 病型 & 癌発見契機 & 大腸癌部位 & $\begin{array}{c}\text { Dysplasia } \\
\text { の有無 }\end{array}$ & $\begin{array}{c}\text { pStage } \\
\text { (深達度) }\end{array}$ \\
\hline M & 42 & 14 & 小腸大腸型 & 肚門痛 & Rectum & 無 & IV \\
\hline M & $\begin{array}{c}30 \\
(17)\end{array}$ & 13 & 小腸大腸型 & 肚門痛 & $\underset{\text { (3 型) }}{\text { Rectum }}$ & 無 & IIIb (a2) \\
\hline M & $\begin{array}{c}46 \\
(38)\end{array}$ & 9 & 小腸大腸型 & 腹部膨満感 & $\begin{array}{c}\mathrm{A} / \mathrm{C} \\
(3 \text { 型 })\end{array}$ & 有 & IIIb (si) \\
\hline $\mathrm{F}$ & $\begin{array}{c}33 \\
(17)\end{array}$ & 16 & 小腸大腸型 & surveillance & $\begin{array}{c}\mathrm{T} / \mathrm{C} \\
\text { (IIc 様) }\end{array}$ & 有 & II $(\mathrm{ss})$ \\
\hline
\end{tabular}

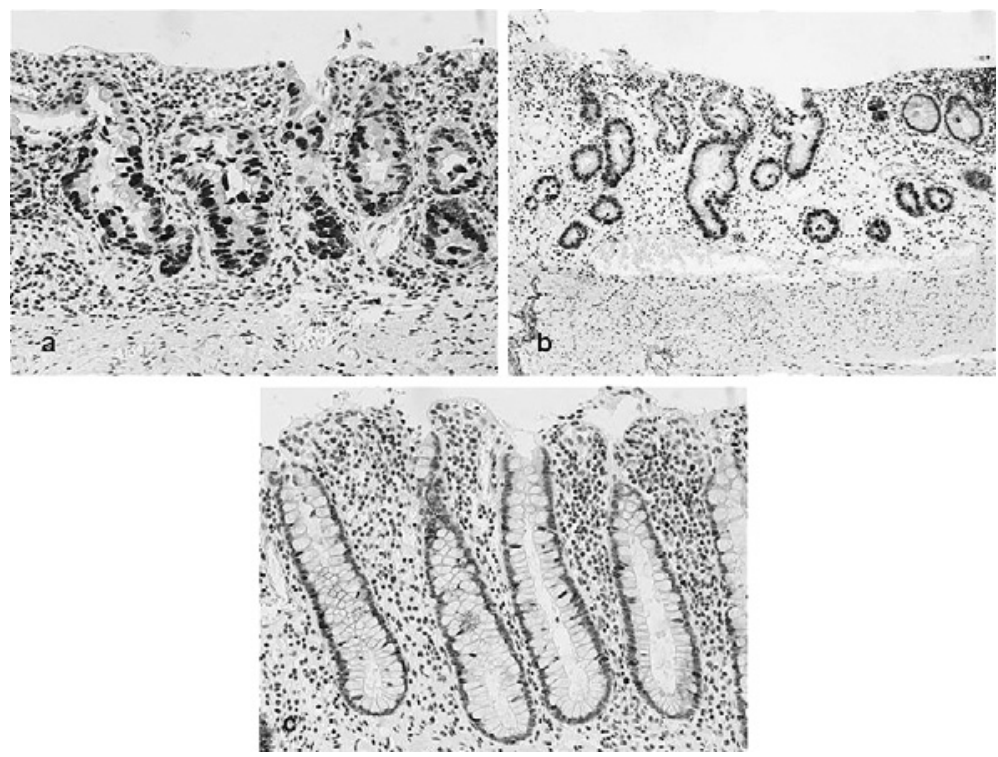

図 $6 \mathrm{Ki}-67$ 免疫染色

high grade dysplasiaでは明らかに正常粘膜に比べ強陽性に染まり, low grade dysplasia も正常部分と比較してやや染まりが強かった。（a：HGD, b：LGD, c： 正常部位)

イランス内視鏡システム確立の必要性が示唆される.

\section{文献}

1) Canavan C, Abrams KR, Mayberry J: Meta-analysis: colorectal and small bowel cancer risk in patients with Crohn's disease. Aliment Pharmacol Ther 23: 1097-1104, 2006

2) Alexander C, George R, Julian T, et al: The risk of cancer in patients with Crohn's disease. Dis Colon Rectum 50: 839-855, 2007

3) Hamilton SR: Colorectal carcinoma in patients with Crohn's disease. Gastroenterology 89: 398-407, 1985
4) Robert EP, Seid HM, Richard GF: Crohn's disease and intestinal carcinoma: A report of 11 cases with emphasis on associated epithelial dysplasia. Gastroenterology 93: 1307-1314, 1987

5）八尾哲史, 岩下明德, 西村 拓ほか：Crohn 病に合併し た大腸癌 4 例の臨床病理学的検討. 胃と腸 $37: 1047-$ 1058, 2002

6) Rashid A, Hamilton SH: Genetic alterations in sporadic and Crohn's-associated adenocarcinomas of small intestine. Gastroenterology 113: 127-135, 1997

7) Friedman S, Rubin PH, Bodian C, et al: Screening and surveillance colonoscopy in chronic Crohn's colitis. Gastroenterology 120: 820-826, 2001

8）味岡洋一, 渡辺英伸, 小林正明ほか：潰瘍性大腸炎に合 併する大腸癌・dysplasia の肉眼・実体顥微鏡像と生検 組織診断。胃と腸 $30 ： 629-642,1995$ 


\title{
A Case of Transverse Colon Cancer Associated with Crohn's Disease
}

\author{
Koichi Nakamura $^{1)}$, Toshio Nakamura ${ }^{1)}$, Kiyotaka Kurachi ${ }^{1)}$, Tadataka Hayashi' ${ }^{1)}$, Akihito Nakajima ${ }^{1)}$, \\ Atsuko Fukazawa $^{1)}$, Shohachi Suzuki ${ }^{1}$, Hiroyuki Konno ${ }^{1)}$ and Satoshi Baba ${ }^{2)}$ \\ ${ }^{1)}$ Second Department of Surgery, ${ }^{2)}$ Pathology, Hamamatsu University School of Medicine
}

A 33-year old woman had been undergoing annual checkups by colonoscopic examination for Crohn's disease for 15 years. During a regular checkups she was diagnosed with transverse colon cancer and so was referred to our hospital. Colonoscopy revealed severe inflammation, with irregular and granular changes in the transverse colon. Because the biopsy tissue from this lesion had small epithelioid cell granuloma, we diagnosed the condition as a transverse colon cancer associated with Crohn's disease. As a result, we performed laparoscopic assisted subtotal colectomy. Pathological examination of the resected specimen revealed a mucinous adeocarcinoma with adjacent dysplasia, ss, ly $1, \mathbf{v} 1, \mathrm{no}$. We experienced a case of transverse colon cancer involving circumjacent dysplasia associated with Crohn's disease. We present this case with some references to the literature. 